\title{
Reflection of Modern Civilization with All Its Degenerative Facets in Prufrock
}

\author{
Ayan Sardar \\ English Educator \\ University of Calcutta \\ Kolkata, West Bengal, India \\ sardarcu23@gmail.com
}

\section{Abstract}

The proposed research article is an attempt to make an analysis and understand the concept of spiritual degeneration and materialism of modern civilization as reflected in TS Eliot poem "Love song of J Alfred prufrock" . Eliot has given English poetry a new direction where the poet must not remain confined within his own self , but must merge with his individual self in the social milieu, the public environment.Modern men become spiritually dead, they lack social value and have only love for materialistic outlook. The present poem holds up the mirror to understand the complex culture, spiritual degeneration and the post-industrial condition of the modern man that is relevant today. The present work discusses how the poem is still relevant to modern society, to modern value and to modern outlook with its modern and penetrative poetic idea.

Keywords: Spiritualism, Degeneration, Modern Civilization, Modern Man.

Eliot is a voice which seems to speak for many of his contemporaries in Europe. $\mathrm{He}$ may well be the greatest poetic influence in the world today. He desires to bring poetry out of the land of rainbows and daffodils to the world of factory chimneys, pubs and herlots and all the things to which we are surrounded today. His first remarkable poem. The Love song of J. Alfred Prufrock, which is dated 1917, re-presents a complete departure from the conventional 
poetry of the 19 th century and is an entirely new beginning. In his essay on Metaphysical poets, he writes-" poets in our civilization must be difficult. Our civilization's complexity, playing upon a refined sensibility, must produce various and complex results. The poet must become more comprehensive, more allusive, more indirect, in order to force to dislocate devices, cultivate all the possibilities of words in order to express entirely a new condition".

Eliot's poetic insights developed under the great influence of Dante and French symbolists especially by Laforgue and Baudelaire. He was moved by the sentiment of Les Fleurs $d u$ Mal- by its rhetoric, its range of its magical language and its concern about degradation and corruption. Eliot was attracted by the sense of modernity in Baudelaire and he accepted it as his own. The sense of decadence in modern life was a constant companion to Eliot. His works breathed his thoughtful and rather pessimistic attitude to modern metropolitan life.

The poetic idea of Prufrock expresses a new kind of thought of Eliot's new poetry. Prufrock is a modern man who lacks spirituality and is unable to face the actuality. Like a modern man Prufrock lacks spontaneity that is indicated in the poem, the dull lethargic existence, the artificial sophisticated mode of living without any purpose or him in a modern city striking revealed in the poem.

"I shall wear the bottom of my trousers rolled".

The poem reflects the utter decadence of modern civilization and modern man there is a presentation of imagery of etherized patient lying on the operation table without the living power of action or feeling is an imaginary that represents the decadence of modern man that the modern man remains alive ,but not vital enough to react emotionally or intellectually. Modern man has sense but lacks sensitivity, like Prufrock modern man suffers from indecision and confusion. 
The atmosphere and the livings of the people or Prufrock presented in the poem still relevant to modern civilization today. This modern urban life has a deadening effect and there is a desired in a modern man to escape it or to overcome it, of course not directly but rather cowardly and fancifully. Prufrock wants to overcome the problem of his own modern life. He seeks refugee in a world, full of artificial glare and pleasures where sex and cheap entertainment may bring temporary relaxation. But this is no the permanent way out of these problems. Eliot sharply brings out the silliness and the trivialities of modern life and their insignificant existence of modern man and women and their tastes in a sarcastic way- " I have measured out of my life with coffee spoons" and also express his irony through the mention of famous

personalities such as Michael Angelo.-

" In the room the women come and go talking of Michelangelo"

Here we find the example of modern man's lack of test of art and aesthetic pleasure.

Deterioration of morality is an example of modern civilization. For Prufrock love is not a divine or emotional it is materialistic which is the manifestation of mundane and sexual pleasure. In the pale and depressing evening of the industrialized society Prufrock wishes to walk through the half deserted streets inhabited mostly by the poor wretched people. There are cheap hotels and restaurants of lower standards in the place. Here we find the restlessness and the consequences of industrialized society. The scenario is quite relevant today. Prufrock is a modern man of spiritual degeneration.

Prufrock is haunted with the sense of his own ineptitude and incompetence. He tries his best to be dressed smartly but the dress did not fit him well as he is well aware of his age, lean figure and baldness. Prufrock suffers from indecision and hesitance, he lacks courage that is the big problem to him. Thus the restless and the neurotic and the the degenerative modern mind is symbolized through the hero of the poem

,prufrock is a symbol of modern man. 
Eliot exploits the personality of prufrock only to expose the nature of a typical modern man, average, not ambitious or willing not daring, suffering from indecision and lacking initiative, living in the monotonous urban civilization. Prufrock is thinking of proposing but missing the courage and inspiration to proceed his aim ,he is restless and suffers from confusion. He is lacking spiritual elevation and mental inspiration.

Eliot's pessimistic outlook of modern civilization is well exploited in the poem. Prufrock hesitation and preference to postpone men indicate the modern average man's lack of spirit and initiative in facing the situation. This is because modern man is nurtured in mechanization, artificiality of urban civilization.Prufrock's journey is a journey to find something meaningful but at the end of totally disillusioned. Like a modern man he knows his limitations he does not wish to be a great figure like

Prince Hamlet but to remain a simple modern man in the general drama of life.

The smoke, the fog and the dullness of the evening is similar to the dullness of the urban civilization. Prufrock is the product of such urbanization like a modern man. He lost in deep confusion. Eliot who is a great disciple of Dante, presents the modern civilization in this poem ,the urban civilization is like a modern Inferno that confined the human soul and put him into suffering. Prufrock is suffering which is predestined to him. Urbanization brings luxury and comforts but degenerates the moral values.

Elliot is spoke person of modern civilization. The post war brought a despair and disilllusion to the young generation. Religion has lost its spiritual appeal, societies live less without any direction, women are the greatest victims of the moral decay of urbanization society, so the poem is a good example of this blazing truth. The pleasure seeking women and also their sarcastic taste of art is well presented through the introduction of a great personality like Michelangelo. The poem is a observation of the meannes and drabness of urbanized society. Through the mind of prufrock Eliot successfully it transmits is idea into sensation. 
In the poem we have a series of picture of modern life ,modern trivialities and absurdities. Sach pictures are precise and pointed as they are served to bring out distinct what is lifeless and trivial in modern life, so complicated and confused.

The hero is restless and suffers from confusion, indecision is an emblem of modern man. We live in 21 st century, and everything is precious and relevant with the poem, Prufrock symbolises every man of the century as we became neurotic suffer from indecision ,hesitance and also confusion. Sometimes we are suppressed by the ideals of materialistic and metropolitan civilization and lost our natural instinct. Prufrock brings out properly the inertia of a modern man and his inner conflict.

Indeed, Prufrock's Monologue serves to reveal the hollowness of modern life with all its artificiality and insignificance. As an average modern man as drawn by Eliot prufrock is found to suffer from indecision and a resolution and that is found in the constant repetition of his love song. In fact the entire monologue is a penetrative account of an average men sense of indecision and hesitation and tendency to evasion. The whole situation exposes the ironic contradiction ,inherent in modern metropolitan living to which Prufrock is a pathetic prey and so the modern man. 


\section{Bibliography}

Gardner,Helen. The Art of TS Eliot. P. 84(Dry season) Faber and Faber Limited (1969), London

Edited by Sullivan, Sheila. Critics on T.S Eliot.P.15(D.Maxwell, Early poems). Universal book stall, New Delhi.

Titus, T.K. A critical study of T S Eliot's works.P.63(Social criticism in Eliot'spoetry) Atlantic Publishers (1999), New Delhi.

Eliot,T.S, The metaphysical poets . Times Literary supplement, 1921

Smith, Grover. T.S Eliot's Poetry and Plays. P.17-18 University of Chicago press (1974), Chicago.

Collected poems of T.S Eliot,P.03, Harcourt, Brace and world Inc. 1952 